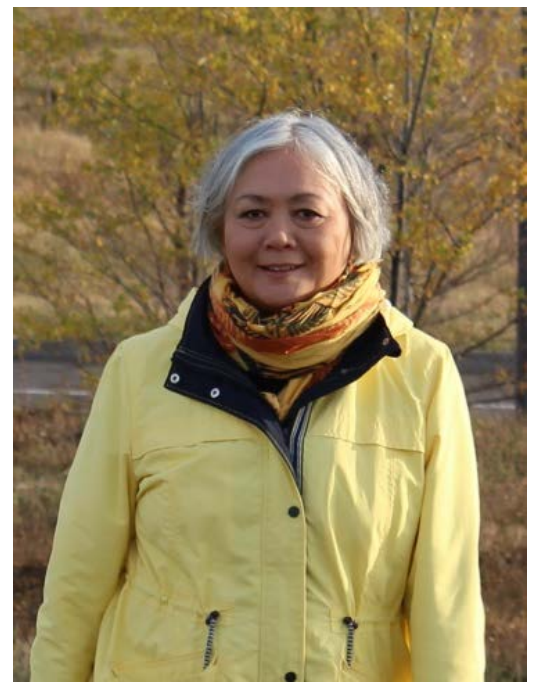

Kulshat Agibaevna Medeuova, Doctor of philosophy, Professor

Department of Philosophy of the L. N. Gumilev Eurasian national University Nur-Sultan, Kazakhstan mkulshat@mail.ru

DOI 10.31554/978-5-7925-0571-1-2019-2-136-142

\title{
SUBURBS OF ASTANA/NUR-SULTAN: FROM THE GREEN BELT TO THE COTTAGE CHAOS
}

The report focuses on the factors that influenced the development of new suburbanization processes in Kazakhstan, and how, after the transfer of the capital from Almaty to Astana in 1997, a communication channel with a rapidly and sometimes chaotically developing capital "opened" in small settlements. The nature of preventive measures against uncontrolled growth of outskirts and suburbs is analyzed. Discussions on the nature of the growth points of the new capital are considered on the examples of plans and implementation of programs "Zhasyl El", "Green zone of the capital", activities for the formation of a sustainable "food security zone". The main provisions and metaphors of the development of the general plans of the capital and suburbs, the gradual transition from the metaphor of symbiotic growth to the rhetoric of agglomeration development are analyzed. The General context of the post-Soviet reformatting of ideas about life in the private sector and the features of pendulum migration is considered on the examples from two settlements Koyanda and Rodina.

Keywords: capital, general plan, suburban area, agglomeration, green zone, state programs.

In the official and unofficial discourses of the new capital of Kazakhstan the concept of "agglomeration" does not seem to be the key yet, centering 
the whole range of tasks of the rapidly growing space of the capital and its suburban areas. And this is despite the fact that two consecutive documents were adopted: "Interregional action plan for the development of Astana agglomeration until 2020" in 2013 [Resolution 2013]; and "Long-term plan for the formation of Astana agglomeration until 2030" in 2018 [Resolution 2018]. Both documents rather outline the general configuration of the territories adjacent to the capital, and then they describe the opportunities for development according to standard scenarios, which in fact repeat the norms of description typical for the last century with all the hierarchical relations of the center-periphery. Thus, one of the key concepts of the 2013 document were "food security of the capital" and "green zone of the capital". Among the priority sectors and clusters of development of Astana agglomeration the tasks of supplying the capital with food dominate. Economic specialization for agglomerations is focused on crop and livestock production, with emphasis on the fact that the suburban area is an infrastructurally coordinated zone around the core city of Astana. As risks the problem of pendulum migration to the capital is noted: “Astana agglomeration is a monocentric agglomeration, which, in addition to the city of Astana, includes the city of Akkol and 4 rural districts of Akkol, 13 rural districts of Arshaly, 18 rural districts of Tselinograd, 11 rural districts of Shortandy districts. These territories are included in the 1.5-hour isochrona of transport accessibility (that is no more than 110 kilometers along the main routes and no more than 75 kilometers in other areas) from Astana. This isochrona corresponds to the international practice of intensive daily labor migration to the core city from adjacent settlements" [Resolution 2013].

A broader framework of regional development was presented by the program "Zhasyl Damu" (Green development) [Decree 2010], according to which the creation of a green zone around Astana is part of larger measures for forest reproduction and afforestation, greening of settlements. This program is a long-term investment in the formation of a comfortable landscape around the capital, aimed at the development of tourism, hunting and recreation. Since Korgalzhyn reserve, state national park "Burabay”, Yerementausky and Atbasar reserves are located in the immediate neighborhood of the external borders of the agglomeration, the green zone of the capital eventually turns into a belt linking the natural, social and cultural landscapes of Central and Northern Kazakhstan. This corresponds to the key idea of Kise Kurakawa (the author of the general plan of the capital), according to 
which the city will never stop in its development, because it will be in constant symbiosis with nature. According to the recommendations of the Japanese architect, it is important for Astana to maintain communication with the cultural and natural landscape through the preservation of nature in the structure of the urban landscape [Bekus, Medeuova 2011].

The rest of the city is made up of "Green wedges", which include individual flora and fauna from all the territories of Kazakhstan and together with parks, embankments along the rivers Yessil, Akbulak, Sarybulak and Nura-Yessil canal, forming a single natural landscape complex, located within walking distance from any territory of the city. The area of greening of the total territory of the city will be $51 \%$ [Regulation... 2013].

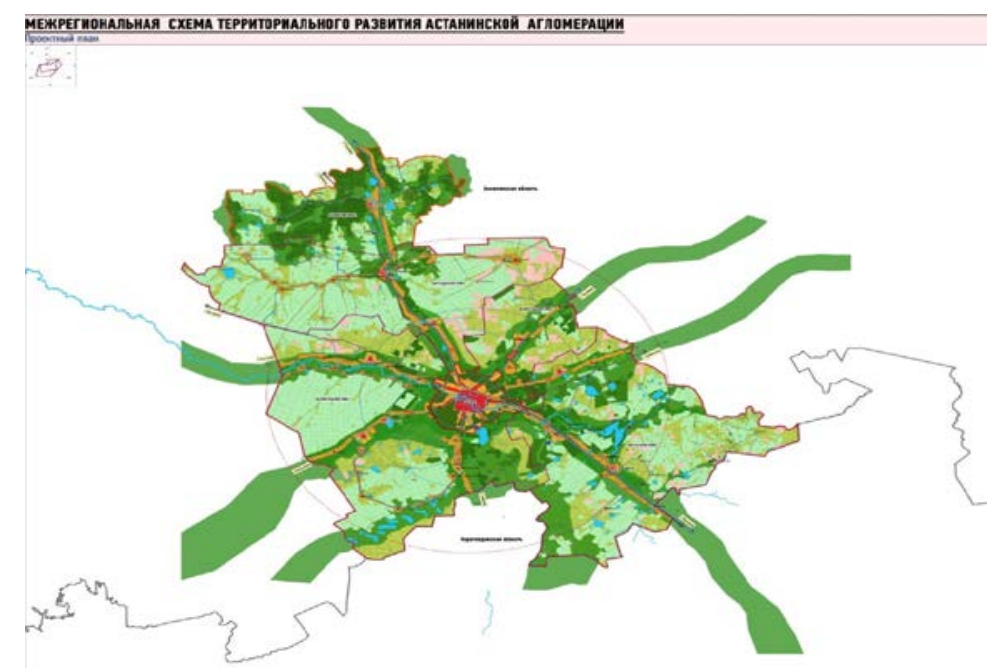

Pic. 1. Interregional scheme of territorial development of Astana agglomeration

According to the first document (Interregional plan... 2013), a positive scenario that Astana can implement is the normalization of the economic and natural landscape load on the territory, which previously mainly specialized in agriculture. According to the second document (Long-term plan... 2018), adopted after the implementation of the EXPO-2017 project, Astana is already interpreted not only as a center of agglomeration, but also as a magnet center. The optimism of the plan's developers about the city's ability to be a magnet is questionable precisely in terms of how the potential of 
suburban areas is interpreted. "Astana has the potential to acquire the status of a magnet city for talented professionals from Western Siberia and Central Asia (Billeter index 19.4\% in 2016) [...] The main goal of the Long-term plan is the formation of Astana agglomeration as an economic center of the Eurasian continent, attractive to the population of Kazakhstan and other countries, primarily for holders of new knowledge, ideas (talents), able to implement them" [Resolution... 2018].

Out of all the new tasks reflected in the second document agglomeration management is in the last place, despite the fact that twenty years of active reformatting of life in the immediate vicinity of the capital have led to uneven development of settlements. And if it was possible to keep the outer suburban areas at some distance from the immediate city limits, the cottage development carries huge risks in terms of planning chaos and lack of provision of public utilities. At the same time, the population of Astana agglomeration was 1,237 thousand people on January 1 in 2018, 1,029 thousand people of which lived in Astana.

Both in the first and in the second documents real possibilities for realization of the tasks declared in preambles of documents are poorly registered: "A set of measures will be taken to bring the quality of life on the outskirts of Astana to the conditions of the city center (the quality of housing, the state of social and engineering infrastructure, and others). Measures will also be taken to prevent the growth of the core city and other settlements at the expense of agricultural and recreational land, bringing the density of the urban population to at least 1,000 people per square kilometer".

Points of positioning of tourist and recreational services, the use of free land for the creation of ecological villages and ethnic villages with mandatory infrastructure for their maintenance were added to the initial ideas about the economic specialization of promising rural settlements in the suburban area of the city.

To validate these plans let us consider some aspects of the real growth of two settlements: Rodina and Koyanda. Rodina aul (until 2010 the village of Priozernoye) received its name from the well-known diversified agricultural formation, a special Kazakh brand of the agricultural firm "Rodina". In the first document this settlement was taken as an example of "perspective". Neither territory nor population has ever been taken into account in terms of rapid growth. For the entire post-Soviet period the population ranged from 1,000 to 1,200 inhabitants, half of whom are employees of the agricultural firm. There is no pendulum migration in relation to the capi- 
tal. To get to work in an agricultural firm and get a social package, it is necessary to pass a kind of competition, in which important parameters are not only professional skills, but also social habits, such as intolerance to alcohol. The village plays not only its economic role but also the role of an exemplary settlement. During the year it is visited by about 100 international delegations, strict control over the entire public space is maintained in the village, the agricultural formation creates an active social program to support its employees, instead demanding their absolute loyalty as residents of the village, for example, the refusal of private farmstead.

The second settlement of Koyanda is the complete opposite of Rodina.In the Soviet period it was home to about 300 people and there was no special specialization in the settlement except livestock farms. Therefore, in the first document, it was assigned the role of a counter-regulator for the uncontrolled growth of suburban areas. The settlement was beyond the half-hour accessibility to the capital and it was assumed that if there were to give plots to various social groups (large families, oralmans, immigrants) away from the immediate city limits, there would be less load on the capital. But the reality was very different. For twenty years the territory of the settlement has increased 18 times, and the population 90 times. According to the data of 2018, 29 thousand people lived in the settlement, about 200 households were located in self-occupied territories.

If the village of Rodina embodies the late Soviet version of prosperity, order, equidistant (equalizing) social environment, where all residents can live in almost identical houses, behind the same fences, the village of Koyanda is the other extreme-chaotic construction, widespread lack of fences, or, conversely, the construction of very high and impenetrable fences. At the same time, if the Soviet-built houses in Rodina are as a "sample" of private housing, in Koyanda it is the buildings of the Soviet period that look like ruins, because the rest of the village, which has grown chaotically, is represented by large cottages. Large cottage houses are not centered in relation to the boundaries of plots, planning lines. The absence of fences, front gardens, combined use of residential and commercial premises leads to an absolutely "non-Soviet" picture of life on "land". With all these "unusual" images the village of Koyanda does not look like a favela or a slum, on the contrary, it is a settlement where the capital's small and medium-sized business actors live, for whom work and life are divorced within the daily pendulum migration. 

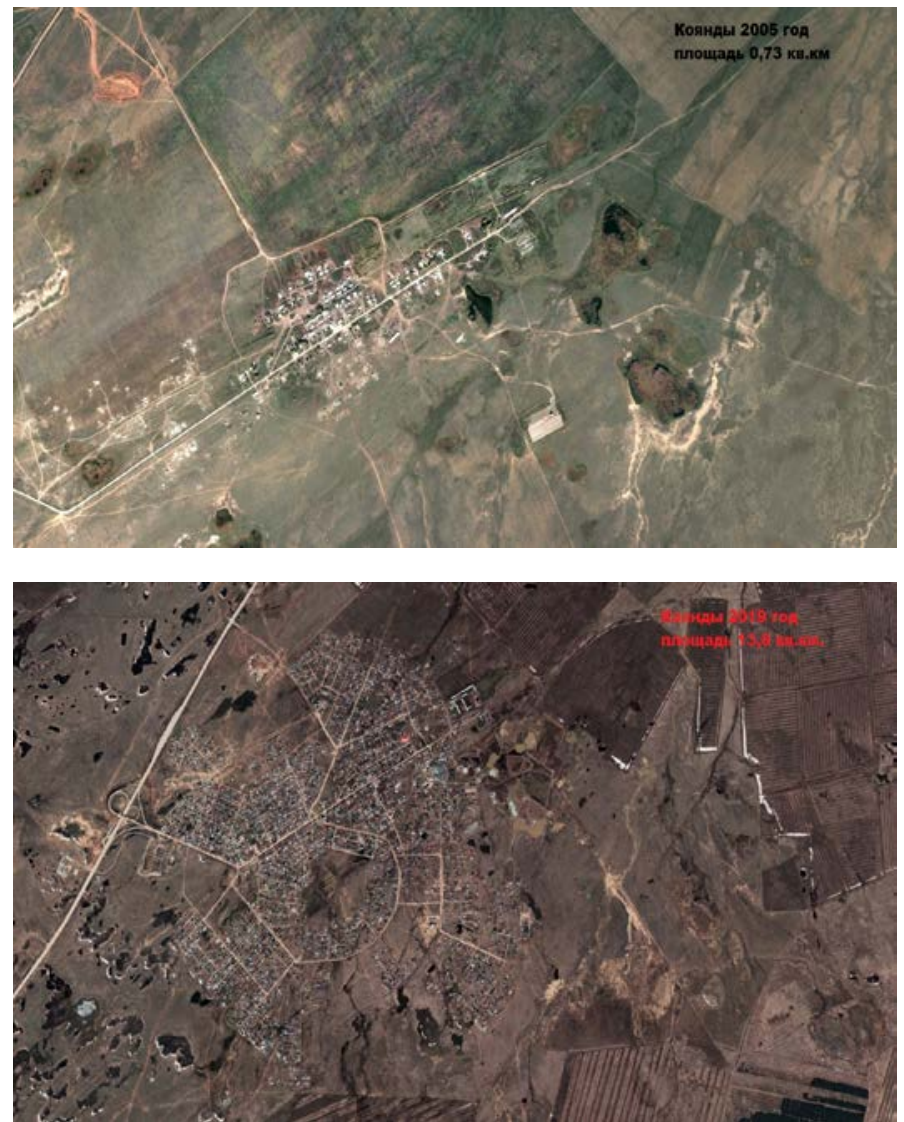

Pic. 2-3. Koyanda in 2005 and in 2019

One of the answers to the different picture of life within half an hour of the capital is that for many theorists, developers of general plans, schematic diagrams of the distribution of productive forces in Kazakhstan the task is still urgent - to find one's own tool for analyzing the emerging cultural practices of life on land. Because in case of preservation of the Soviet pattern of conducting collective economy and binding the settlement to it the picture of "the improved Soviet" turns out. In the case of granting full freedom to residents themselves to "cultivate" their territories the methodological insufficiency of urban planning analytics becomes apparent. The task is to learn how to analyze the real processes of reformatting ideas about life on land. 


\section{References and sources}

Postanovleniye Pravitelstva Respubliki Kazakhstan ot 18 Iyunya 2013 № 611 "Ob utverzhdenii Mezhregionalnogo plana meropriyatiy po razvitiyu Astaninskoy aglomeratsii do 2020" [Resolution of the Government of the Kazakhstan Republic dated June 18, 2013 No. 611 "On approval of the interregional action plan for the development of Astana agglomeration until 2020".]

Postanovleniye pravitelstva Respubliki Kazakhstan ot 26 Iyulya 2018 № 862 "Ob utverzhdenii dolgosrochnogo plana formirovaniya Astaninskoy aglomeratsii do 2030" [Resolution of the government of the Kazakhstan Republic dated July 26, 2018 No. 862 "On approval of the long-term plan for the formation of the Astana agglomeration until 2030"].

Ukaz Presidenta Respubliki Kazakhstan ot 1 Fevralya 2010 “O strategicheskom plane razvitiya RK do 2010": Pravitelstvom razrabotana I utverzhdena otraslevaya programma “Zhasyl Damu” na 2010-2014” [Decree of the President of the Kazakhstan Republic dated February 1, 2010 "On the strategic development plan of Kazakhstan until 2020"; the government has developed and approved the sectoral program "Zhasyl Damu" for 2010-2014].

Bekus N. E., Medeusova K. A. Smena epokh kak smena stolits: Astana kak globalniy centre [The change of epochs as the change of capitals: Astana as a global centre] // Vmesto pamyati: sovetskoye segodnya [Emergency ration. Instead of memory: soviet today]. - 2011. - № 80. - P. 139-158. 